УДК 621.384.2:621.791:615.462-036

DOI https://doi.org/10.32838/2663-5941/2020.2-2/25

Таланюк В.В.

Інститут електрозварювання імені С.О. Патона Національної академії наук України

Шадрін А.O.

Інститут електрозварювання імені Є.О. Патона Національної академії наук України

\title{
Юрэенко М.В.
}

Інститут електрозварювання імені С.О. Патона Національної академії наук України

Кораб М.Г.

Інститут електрозварювання імені С.О. Патона Національної академії наук України

\section{ДОСЛІДЖЕННЯ ТА РОЗРОБКА ТЕХНОЛОГІЇ ФОРМУВАННЯ ЗВАРНИХ З'СДНАНЬ ЗРАЗКІВ 3 БІОДЕГРАДАБЕЛЬНИХ ПОЛІМЕРІВ ТИПУ ПОЛІГІДРОКСИБУТИРАТ/ПОЛІЛАКТИД (ПГБ/ПЛА)}

Сьогодні ми стикасмося з проблемою відитовхування екологічного тиску синтетично- або нафтохімічно отриманими продуктами. Економічний фактор виходить з екологічно безпечних досліджень матеріалів і виробів, властивості яких виконують екологічні та економічні вимоги. Багато переваг для спільноти створила нафтохімічна промисловість на основі полімерної технології. Одна з цих перевагвикористання пластику лише в упаковиі. Зручність, безпека, низька иіна і хороші естетичні якості є найбільш важливими факторами, що визначають швидке зростання у використанні пластмас у пакувальній промисловості. Спалювання таких відходів продукує велику кількість діоксиду вуглецю, що сприятиме глобальному потеплінню. Ці екологічні проблеми створили гостру необхідність розвитку еко-полімерних матеріалів, які не пов'язані з використанням токсичних і шкідливих компонентів у їх виробництві і можуть розкладатися в природі. 3 иих причин сьогодні у світі предметом великої науково-дослідницької задачі для вчених та інженерів є розробка біорозкладних матеріалів з регульованими властивостями. $3 a$ допомогою інноваційних технологій поновлювані ресурси можуть бути замінені на нафтові полімери на біополімери. Також зростає актуальність розробки нових продуктів на основі біо- та інших інноваційних технологій, які можуть зменшити широко поширену залежність від викопного палива і в той же час сприяти підвищенню національної безпеки, охорони навколишнього середовища та економіки.

Експериментально досліджували зварюваність плівок із біорозкладних полімерів. Біорозкладну плівку із суміші полімерів ПЛА/ПГБ зварювали ультразвуковим методом на стандартній установці пресового типу фірми Branson.

Напускні шви біорозкладної плівки, зварені профільованим сонотородом, формувались з утворенням рівномірного проплавлення по усій площі з'єднання. На зовнішній поверхні шва спостерігаються невеликі фрагменти деструктованого полімерного матеріалу, щз утворюються через кониентрацію механічних напружень та підвищення температури на пікових виступах профільованої поверхні сонотроду. Усі напускні зварні з'єднання біорозкладних плівок, виконані ультразвуковим способом, при випробуваннях на розтяг руйнувались по основному матеріалу.

Структура зварних з'єднань біорозкладних полімерів біла досліджена рентгенівським методом ширококутового розсіювання променів. Приведені дифракиійні графіки для основного матеріалу зразків, щзо використовувались в експериментах по зварюванню.

Ключові слова: біополімери, зварні з'єднання, ширококутові рентгенівські дифрактограми.

Постановка проблеми. Сьогодні ми стикаємося 3 проблемою відштовхування екологічного тиску синтетично- або нафто-хімічно отриманими продуктами. Економічний фактор виходить 3 екологічно безпечних досліджень матеріалів і виробів, властивості яких виконують екологічні та економічні вимоги [1].
Дослідження біополімерів не обмежується продуктами, а вказує на те, що ці полімери можуть зіграти важливу роль в інших сферах досліджень. Ми ж очікуємо побачити використання біополімерів на рівні з синтетичними пластмасами, що використовуються сьогодні у сферах упаковки, медицини, будівництва, майже в кожній частині життя [2]. 
Одним із найперспективніших біопластиків для застосування в упаковці вважається полілактид - продукт конденсації молочної кислоти. Його отримують як синтетичним способом, так і ферментативним бродінням декстрози цукру або мальтози сусла зерна і картоплі, які є поновлюваною сировиною біологічного походження [3].

Полілактид (ПЛА) - прозорий безбарвний термопластичний полімер. Його основна перевага це можливість переробки всіма способами, притаманними для переробки термопластів [4].

3 аркушів полілактиду можна сформувати тарілки, підноси, отримати плівку, волокно, упаковку для харчових продуктів, імплантанти для медицини. Але його широке застосування стримується низькою продуктивністю технологічних ліній і високою вартістю одержуваного продукту [5].

Інший біополімер, що займає значне місце у промисловому виробництві - полігідроксибутират (ПГБ) - біополімер, що подібний полістиролу за своїми фізичними властивостями. Він був виявлений у бактерії Alcaligenеs eutropus. ПГБ швидко руйнується грунтовими мікроорганізмами. Полімер отримують при вирощуванні Azotobacter на глюкозі з лімітацією кисню, також Alcaligenes при дефіциті азоту в біологічно активному середовищі [6].

Пластичні маси на основі відтворюваних природних компонентів - це пластмаси, до складу яких можуть входити крохмаль, целюлоза, хітозан, протеїн. 3 композицій на їх основі створюють одноразовий посуд, плівки для пакування та сільського господарства тощо. Початковою сировиною для біохімічного процесу служить крохмаль (маїсовий, кукурудзяний, картопляний, злаковий) або меляса, що отримали при виробництві цукру 3 цукрового буряка або цукрового очерету, а також деяких інших рослинних продутів, що містять гексозани [7].

Важливе місце в дослідженнях займає проблема надання властивостей біорозкладання добре освоєним малотоннажним промисловим полімерам (поліетилен, поліпропілен, полівінхлорид, полістирол, поліетилентерефталат).

Постановка завдання. Метою статті є дослідження та розробка технології формування зварних з'єднань зразків з біодеградабельних полімерів типу полігідроксибутират/полілактид (пгб/пла).

Виклад основного матеріалу дослідження. Матеріали і методи. Експериментально досліджували зварюваність плівок із біорозкладних полімерів. Використовували плівку, призначену для пакування харчових продуктів та виготовлену в лабораторних умовах із суміші полімерів ПЛА та ПГБ. У суміші використовували таку полімерну сировину:

ПЛА - комерційний полілактид типу 2002D виробництва компанії NatureWorks ${ }^{\circledR}$, США. Основні характеристики ПЛА: показник текучості

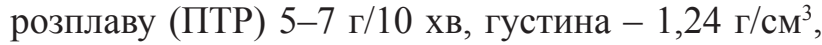
вміст D-мерів нижче 3,5\%, молекулярна маса $\mathrm{M}_{\mathrm{w}}=208000$.

ПГБ був отриманий у лабораторних умовах оригінальним методом, розробленим у Центрі Полімерних і Вуглецевих Матеріалів Польської Академії наук. ПГБ синтезували шляхом полімеризації розчину аніонного кільця (РАК), рацемічного ( $\mathrm{R}, \mathrm{S})$ - $\beta$-бутиролактону в присутності ацетату тетрабутиламонію як ініціатора. РАК проводили навалом при кімнатній температурі. Отриманий полімер розчиняли у хлороформі та протонірували. Потім отриману сировину а-ПГБ осаджували в гексані та сушили у вакуумі при температурі $40^{\circ} \mathrm{C} .[7 ; 8]$.

Результати. Біорозкладну плівку із суміші полімерів ПЛА/ПГБ зварювали ультразвуковим методом на стандартній установці пресового типу фірми Branson (рис. 1). Використовували сонотрод із пласкою горизонтальною поверхнею двох типів - рівна шліфована поверхня та профільована поверхня із регулярними пірамідальними виступами типу «накатка».

Біорозкладна плівка легко плавилась та починала деструктувати при інтенсивному нагріванні, тому зварювання проводили на режимах мінімальної потужності. Робочий тиск становив 0,3 МПа, тривалість прогріву при зварюванні - 2-3 секунди, амплітуда механічних коливань - 40-50 мкм.

Напускні шви біорозкладної плівки, зварені сонотородом із рівною поверхнею, добре формувались, але прогрівання матеріалу було дещо нерівномірним по площі з'єднання. На деяких швах спостерігались невеликі виплески розплавленого матеріалу із зони зварювання (рис. 2).

Напускні шви біорозкладної плівки, зварені профільованим сонотородом, формувались 3 утворенням рівномірного проплавлення по усій площі з'єднання (рис. 3). На зовнішній поверхні шва спостерігаються невеликі фрагменти деструктованого полімерного матеріалу, що утворюється через концентрацію механічних напружень та підвищення температури на пікових виступах профільованої поверхні сонотроду. Усі напускні зварні з'єднання біорозкладних плівок, виконані ультразвуковим способом, при випробуваннях на розтяг руйнувались по основному матеріалу. 


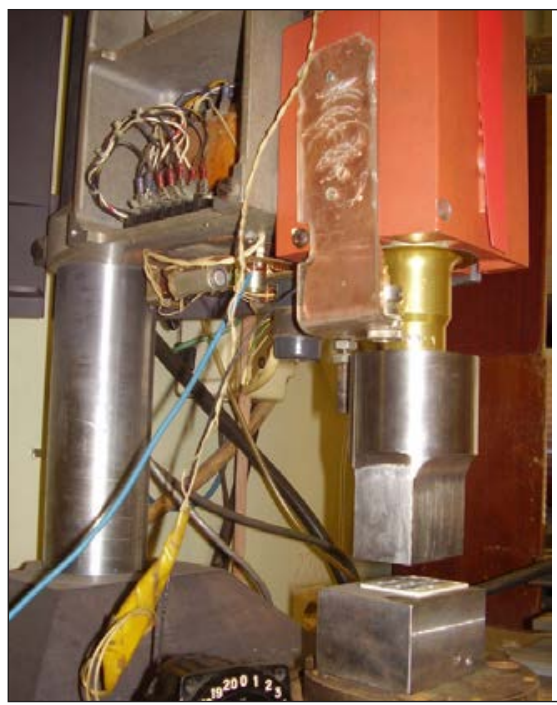

Рис. 1. Установка для пресового ультразвукового зварювання Branson iз пласким сонотродом

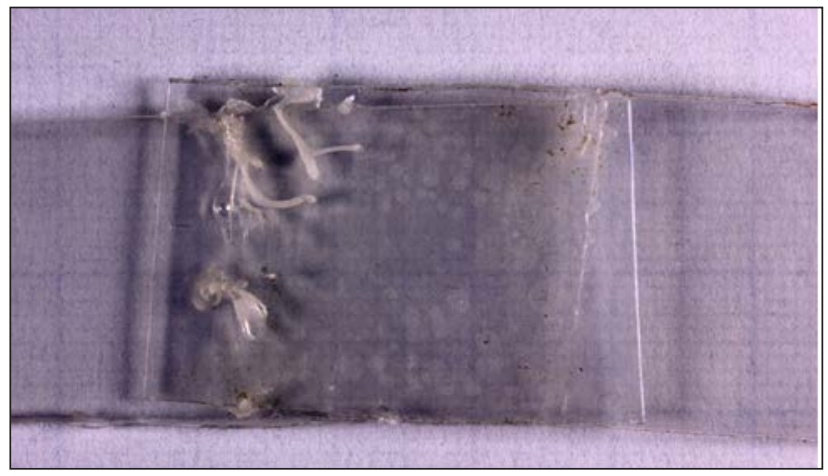

Рис. 2. Ультразвуковий напускний зварний шов біорозкладної плівки, виконаний сонотородом із рівною поверхнею

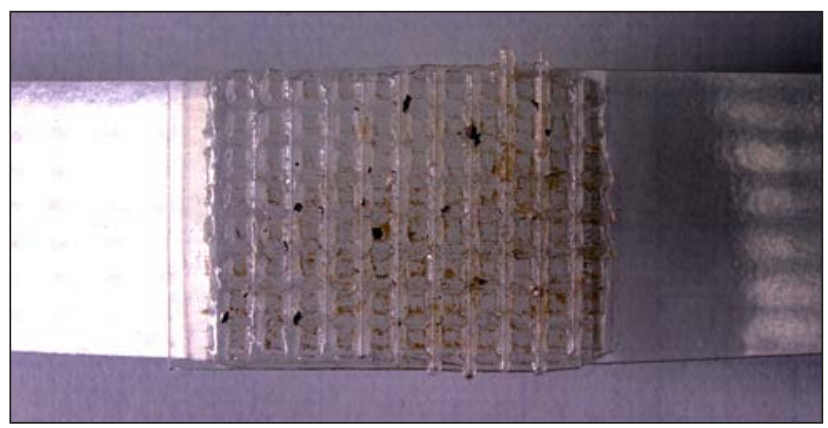

Рис. 3. Ультразвуковий напускний зварний шов біорозкладної плівки, виконаний сонотородом із профільованою поверхнею

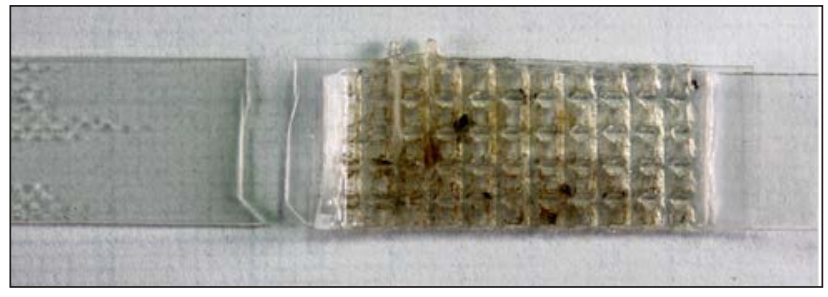

Рис. 4. Руйнування ультразвукового напускного зварного шва під час випробувань на розтяг
Структура зварних з'єднань біорозкладних полімерів біла досліджена рентгенівським методом ширококутового розсіювання променів. На рис. 5 приведені дифракційні графіки для основного матеріалу зразків, що використовувались в експериментах по зварюванню.

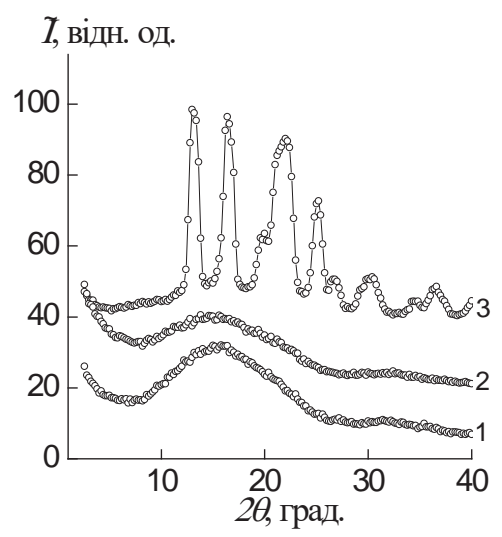

Рис. 5. Ширококутові рентгенівські дифрактограми основного матеріалу зразків біорозкладного пластику: 1- ПЛА, 2 - суміш ПГБ/ПЛА, 3 - ПГБ

Дифракційні криві 1 та 2 не мають явно виражених максимумів, отже, полілактид та суміш ПЛА/ПГБ - це аморфні полімери із низьким ступенем кристалічності. Дифракційна крива 3 має декілька максимумів різної інтенсивності, отже, ПГБ це висококристалічний полімер в надмолекулярній структурі, в якому присутні кристалічні утворення різних форм та розмірів.

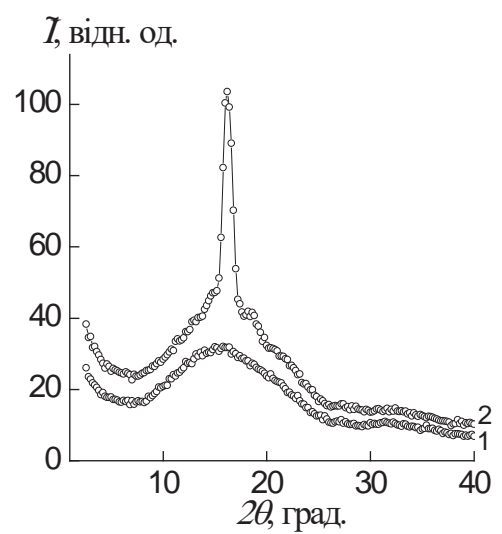

Рис. 6. Ширококутові рентгенівські дифрактограми основного матеріалу ПЛА і з'сднання зразків з ПЛА, звареного нагрітим інструментом встик

Під час порівняння ширококутових рентгенівських дифрактограм основного матеріалу ПЛА і зварного з'єднання, отриманого тепловим зварюванням встик, видно, що після зварювання в структурі полімеру формуються упорядковані 
структури. Про це свідчить потужний одиночний максимум на кривій 2 , рис. 6 . За геометричними параметрами кривої ступінь кристалічності зварного з'єднання зразків з ПЛА можна оцінити у 20\%. Вочевидь, під час формування матеріалу зварного шва в умовах великих температурних градієнтів в полімерному матеріалі формуються невеликі складчасті або пачкові структури макромолекулярних ланцюгів.

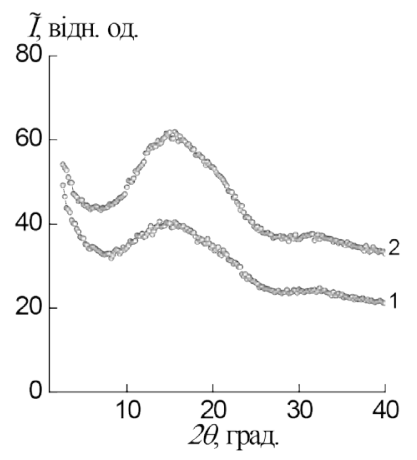

Рис. 7. Ширококутові рентгенівські дифрактограми, основного матеріалу полімерної суміші ПГБ/ПЛА (крива 1)

і ультразвукового зварного з'єднання плівок з суміші ПГБ/ПЛА (крива 2)
Дифрактограма № 2, приведена на рис. 7, показує, що структура ультразвукового зварного з'єднання плівок із суміші ПГБ/ПЛА має певний невеликий кристалічний складник. На це вказують слабко виражений дифракційний максимум при кутах розсіюювання $2 \theta_{\mathrm{m}}=12,8^{\circ}, 15,4^{\circ}$, $19,4^{\circ}$. Дифрактограма № 1 має рівний характер, без жодного максимуму, отже, як структура основного матеріалу біорозкладних плівок із суміші ПГБ/ПЛА має повністю аморфний характер.

Висновки. Отже, під час порівняння ширококутових рентгенівських дифрактограм основного матеріалу ПЛА і зварного з'єднання, отриманого тепловим зварюванням встик, видно, що після зварювання в структурі полімеру формуються упорядковані структури. Про це свідчить потужний одиночний максимум на кривій 2. За геометричними параметрами кривої ступінь кристалічності зварного з'єднання зразків з ПЛА можна оцінити у $20 \%$. Вочевидь, під час формування матеріалу зварного шва в умовах великих температурних градієнтів, в полімерному матеріалі формуються невеликі складчасті або пачкові структури макромолекулярних ланцюгів.

Список літератури:

1. Ramsay J. A., Berger E., Voyer R., Chavarie C., Ramsay B. A.: Extraction of poly-3-hydroxybutyrate using chlorinated solvents. Biotechnology Techniques, 8, 589-594 (1994) DOI: 10.1007/BF00152152

2. Jacquel, N., Lo, C.-W. (2008) Isolation and purification of bacterial poly (3-hydroxy alkanoates) Biochemical Engineering Journal. 39 (1),15-27.

DOI: $10.1016 /$ j.bej.2007.11.029

3. Al-Majed, A.A.; Abd-Allah, A.R.; Al-Rikabi, A.C.; Al-Shabanah, O.A. \& Mostafa, A.M. (2013). Effect of oral administration of Arabic gum on cisplatin-induced nephrotoxicity in rats. Journal of Biochemical and Molecular Toxicology, Vol.17, No.3, (January 2013), pp. 146-153, ISSN: 1099-0461.

4. Jiang X., Ramsay J. A., Ramsay B. A.: Acetone extrac- tion of mcl-PHA from Pseudomonas putida KT2440. Journal of Microbiological Methods, 67, 212-219 (2006).DOI: 10.1016/j.mimet.2006.03.015

5. Yu J., Chen L. X. L.: Cost-effective recovery and purification of polyhydroxyalkanoates by selective dissolution of cell mass. Biotechnology Progress, 22, 547-553 (2006). DOI: 10.1021/bp050362g

6. Amanat N. Welding methods for joining thermoplastic polymers for the hermetic enclosure of medical devices [Text]/ N. Amanat, N.L. James, D.R. McKenzie. Medical Enjineering and physics, 2010. Vol 32, p.p. 600-699.

DOI: $10.1021 /$ ie 9707432

7. Sudesh K., Maehara A., Gan Z., Iwata T., Doi Y.: Direct observation of polyhydroxyalkanoate granuleassociated-proteins on native granules and on poly(3-hydroxybutyrate) single crystals by atomic force microscopy. Polymer Degradation and Stability, 83, 281-287 (2004). DOI: 10.1016/S0141-3910(03)00273-8

8. Effect of Geometry of Filler Particles on the Effective Thermal Conductivity of Two-Phase Systems Department of Physics, Heat Transfer Laboratory, University of Rajasthan, Jaipur, India 2018, Vol. 23, p.p. 605-617.

\section{Talanyuk V.V., Shadrin A.O., Iurzhenko M.V., Korab M.G. RESEARCH OF TECHNOLOGY FOR FORMATION OF WELDED COMPOUNDS OF PHB / PLA TYPE BIOPOLYMERS}

Today, we face the problem of environmental pressure that repels synthetic or petro-chemical products, while economic factors pull them back.

We expect the use of biopolymers just like synthetic plastics are used at the moment. For example in packaging, medicine, construction, in almost every part of life. The polymer is based on petrochemical industry and has been created many benefits for the community. One of these advantages is the use of plastics 
only in packaging. The most important factors determining the rapid growth of the use of plastics in the packaging industry are convenience, safety, low cost and good aesthetic qualities. The incineration of such waste produces a large amount of carbon dioxide, which promotes global warming. These environmental problems have created an urgent need for the development of green polymeric materials that are unrelated to the use of toxic and harmful components in their production and may decompose in nature. For these reasons the development of biodegradable materials with controlled properties is the subject of big research challenge for scientists and engineers. Renewable resources can replace petroleum polymers with biopolymers through innovative technologies. There is increasing relevance for the development of new products based on bio and other innovative technologies that can reduce the widespread dependence on fossil fuels and at the same time contribute to the enhancement of national security, the environment and the economy.

The weldability of films of biodegradable polymers was experimentally been researched. A film intended for the packaging of foodstuffs was used and produced in the laboratory from a mixture of PLA and PHB polymers. The biodegradable film of the PLA/PHB polymer mixture was ultrasonic welded on a standard Branson press type installation. We used a sonotrode with a flat horizontal surface of two types - a flat polished surface and a profiled surface with regular pyramidal projections of the "knurling" type.

Biodegradable film seams welded by a profiled sonotrode were formed to form a uniform penetration over the entire joint area. On the outer surface of the seam, there are small fragments of degraded polymer material formed due to the concentration of mechanical stresses and temperature rise at the peak projections of the profiled surface of the sonotrode. All ultrasonic biodegradable film sealing welded joints were destroyed in the basic material during tensile tests. The structure of welded joints of biodegradable polymers has been studied by X-ray wide-angle scattering. The diffraction graphs for the main material of the samples used in the welding experiments are shown bellow.

Key words: biopolymers, welded joints, wide-angle X-ray diffraction patterns. 